\title{
THE FORM 50 LEASE: JUDICIAL TREATMENT OF AN ADHESION CONTRACT
}

\section{AdHesion Aspects of the Form 50 Lease}

Contracts of adhesion are "agreements in which one party's participation consists in his mere 'adherence,' unwilling and often unknowing, to a document drafted unilaterally and insisted upon by what is usually a powerful enterprise." 1 These agreements are often standardized throughout an industry ${ }^{2}$ in forms containing a myriad of finely printed conditions ${ }^{3}$ unilaterally beneficial to the drafter. ${ }^{4}$ The form 50 lease-which, with its modification for apartment renting, the form 42 , is the most widely used lease in the Philadelphia area-illustrates the theories appropriate to judicial analysis of a form adhesion contract. ${ }^{5}$

Since landlords are unwilling to modify a form whose terms strongly favor them, many tenants have no choice but to sign the lease or reject the entire transaction. If the form 50 lease were literally enforced, the tenant's position would be unfortunate. However, non-literal judicial constructions have weakened some of the form's harsher provisions. Although influenced by the lease's unconscionable elements, the Pennsylvania courts generally have achieved desirable results by couching their opinions in traditional contract language. In other contexts, however, courts have articulated the elements of adhesion actually underlying their decisions. ${ }^{6}$

Reasoned interpretation of a multifarious form lease depends upon choosing legal principles appropriate to the clause under consideration. Recognition of adhesion elements may be dispositive of certain harsh clauses, whereas problems raised by other clauses are peculiar in the use of standardized forms. Most clauses typically found in adhesion contracts, however, are governed by principles equally applicable to bargained transactions.

1 Ehrenzweig, Adhesion Contracts in the Conflict of Laws, 53 CoLvar. L. Rev. 1072, 1075 (1953) ; see Bekken v. Equitable Life Assur. Soc'y, 70 N.D. 122, 143, 293 N.W. 200, 212 (1940); Siegelman v. Cunard White Star Ltd., 221 F.2d 189, 204-07 (2d Cir. 1955) (dissenting opinion).

2 See Henningsen v. Bloomfield Motors, Inc., 32 N.J. 358, 390-91, 161 A.2d 69, 87 (1960).

${ }^{3}$ See Cutler Corp. v. Latshaw, 374 Pa. 1, 97 A.2d 234 (1953) ; Note, 63 Harv. L. Rev. 494 (1950); Note, 109 U. PA. L. Rev. 401, 412 (1961).

4 See Campbell Soup Co. v. Wentz, 172 F.2d 80 (3d Cir. 1948); Note, 58 YALE L.J. 1161 (1949).

5 Mr. Charles W. Lukens of Yeo \& Lukens Co., a publisher of the form 50 lease, states that his company sells substantially more forms 50 and 42 than all other leases combined. Interview With Charles W. Lukens in Philadelphia, Dec. 14, 1962. The form 50 lease is also printed and sold by the John C. Clark Co. It consists of a long folio covered with more than 33 inches of closely spaced 8 point type. References in this Note are to the October 1, 1962 revision of the form, which is substantially similar to earlier editions.

${ }^{6}$ Campbell Soup Co. v. Wentz, 172 F.2d 80 (3d Cir. 1948) (action in equity); State Farm Mut. Auto. Ins. Co. v. Anderson-Weber, Inc., 252 Iowa 1289, 110 N.W.2d 449 (1961) ; Henningsen v. Bloomfield Motors, Inc., 32 N .J. 358, 161 A.2d 69 (1960). 


\section{Non-adheston Theories Supporting Form 50 Lease INTERPRETATION}

\section{A. Public Policy}

Until 1953 the Pennsylvania courts held that exculpatory clauses in leases are enforceable private contracts. ${ }^{7}$ Nevertheless, despite an exculpatory clause, the supreme court in Boyd $v$. Smith ${ }^{8}$ permitted recovery by a tenant injured when a fire forced her to jump from her third floor apartment. The landlord's failure to provide a "safe fire-escape" had violated a state penal statute aimed at public safety, ${ }^{9}$ and the court rested upon the principle that private contracts may not circumvent statutory public policy. ${ }^{10}$ The court properly ignored the additional problem of whether the exculpatory clause was in a form lease. Although adhesion contracts are frequently the occasion for such unilaterally beneficial provisions, the evil in Boydfrustration of safety legislation-does not arise from incidents peculiar to adhesion contracts.

Common pleas courts have extended Boyd to nullify exculpatory clauses where landlords have violated local safety ordinances. ${ }^{11}$ Since most exculpatory clause cases have involved damage or injury due to fire, ${ }^{12}$ explosion, ${ }^{13}$ faulty plumbing, ${ }^{14}$ defective fire escapes, ${ }^{15}$ unsafe stairs, ${ }^{16}$ and structural defects ${ }^{17}$-any of which might violate a statute ${ }^{18}$ or detailed

7 See, e.g., Jacob Siegel Co. v. Philadelphia Record Co., 348 Pa. 245 (1944); Wright v. Sterling Land Co., $157 \mathrm{~Pa}$. Super. 625, 43 A.2d 614 (1945) ; Lerner v. Heicklen, $89 \mathrm{~Pa}$. Super. 234 (1926) (per curiam). The rule is well-established in most jurisdictions. See, e.g., Inglis v. Garland, 19 Cal. App. 2d 767, 64 P.2d 501 (App. Dept., Super. Ct. 1936) ; Clarke v. Ames, 267 Mass. 44, 165 N.E. 696 (1929) ; Burnett v. Texas Co. 204 N.C. 460, 168 S.E. 496 (1933). See generally Annot., 175 A.L.R. 8, 83-94 (1948); Note, 15 TEMP. L.Q. 427 (1941); Note, 15 U. PITT. L. REV. 493 (1954).

8372 Pa. 306, 94 A.2d 44 (1953).

9 Pa. Stat. Ann. tit. 53, $\S 15002$ (1957).

10 See Bell v. McAnulty, $349 \mathrm{~Pa}$. 384, 386, 37 A.2d 543, 544 (1944); Williams v. Wenger, $319 \mathrm{~Pa} .73,179$ At1. 242 (1935) (dictum); McCurdy's Estate, $303 \mathrm{~Pa}$. 453, 461, 154 At1. 707, 709 (1931) (dictum).

11 Maglin v. Weinberg, $21 \mathrm{~Pa}$. D. \& C.2d 630 (C.P. Allegheny County 1959) (defective fire escape); Felegy v. Pinsker, 104 Pittsb. Leg. J. 73 (C.P. Allegheny County, Pa., 1955) (defective gas furnace); Harris v. Greenberg, 17 Pa. D. \& C.2d 166 (C.P. Phila. County 1958) (defective stairs, poor lighting); cf. Bowman v. McGillick, 104 Pittsb. Leg. J. 484 (C.P. Allegheny County, Pa., 1956).

12 Bachrach v. Lupowitz, 66 Montg. Co. L. Rptr. 187 (C.P. Montgomery County, Pa., 1950).

13 Manius v. Housing Authority, 350 Pa. 512, 39 A.2d 614 (1944).

14 Jacob Siegel Co. v. Philadelphia Record Co., 348 Pa. 245, 35 A.2d 408 (1944); Anderson v. Wolfe, 49 Lack. Jur. 173 (C.P. Lakawanna County, Pa., 1947) ; Casual Sportswear, Inc. v. Suravitz, 63 Pa. D. \& C. 93 (C.P. Lackawanna County 1948) ; Pittsburgh Iron Folding Bed Co. v. Barrett Co., 77 Pittsb. Leg. J. 201 (C.P. Allegheny County, $\mathrm{Pa}$., 1928).

15 Baldwin v. McEldowney, $324 \mathrm{~Pa}$. 399, 188 Atl. 154 (1936).

16 Gorel v. Comensky, 58 Pa. D. \& C. 374 (C.P. Allegheny County 1946).

17 Kottler v. Manor Real Estate \& Trust Co., 107 Pittsb. Leg. J. 387 (C.P. Allegheny County, Pa., 1959).

18 See PA. STAT. ANN. tit. 53, $\$ 14751-15176$ (1957) (building regulations applicable to Philadelphia). 
ordinance, ${ }^{18}$-exculpatory clauses are now largely ineffective to protect landlords responsible for commonplace hazards.

In the complex provisions of paragraphs 11 and 12 of the form 50 lease the "Lessee agrees to be responsible for and to relieve . . . the Lessor from all liability" for property damage and personal injury whether such "injury or damage . . . be caused by or result from the negligence of Lessor or its servants or agents or any person or persons whatsoever." Because of this exculpatory language, ${ }^{20}$ Boyd squarely prevents landlord's evasion of future tort liability to tenant. If a third party is injured, however, invalidation of the clause depends on Boyd's application to the indemnity aspects of the language. Cases concerning common carriers permit private indemnification against tort liability, ${ }^{21}$ even though public policy forbids exculpation. ${ }^{22}$ This distinction comports with the general tort objective of recompensing loss, since the usual indemnity clause in favor of a common carrier merely shifts the ultimate obligation for damages to a third-party indemnitor, whereas an exculpatory clause erases all claims of the injured patron. ${ }^{23}$ In the leasing context the Boyd opinion, reinforcing the statutory protection of tenants' safety, also operates to ensure compensation for injury by restricting exculpation. But since tenant and his household suffer the most exposure to injury from landlord's statutory violations, distinguishing the exculpatory clause and requiring tenant to indemnify for injury to himself or his household deprives him of the protection Boyd purports to extend. Accordingly, the rationale of Boyd should encompass lease indemnity clauses.

Form 50 clauses may also be overridden by generally applicable principles of public policy generated by the courts. ${ }^{24}$ Thus, tacitly recognizing

19 See Phila., Pa. Code of General Ordinances tits. 4 (building code), 5 (fire code), 7 (housing code) (1956).

20 In paragraph 11 lessor is relieved "from all liability by reason of any injury or damage to any person or property in the demised premises, whether belonging to the Lessee or any other person . . . ." (Emphasis added.) Two common pleas cases have recognized that the lease exculpates landlord from liability to tenant. McDonough v. Plantholt, 76 Pa. D. \& C. 119 (C.P. Phila. County 1950); Williams v. Wolf, $83 \mathrm{~Pa}$. D. \& C. 399, 406 (C.P. Phila. County 1952) (dictum). But cf. Inglis v. Garland, 19 Cal. App. 2d 767, 770, 64 P.2d 501, 502-03 (App. Dep't, Super. Ct. 1936).

21 See, e.g., Law v. Reading Co., 312 F.2d 841 (3d Cir. 1963) ; Seaboldt v. Pennsylvania R.R., 290 F.2d 296 (3d Cir. 1961). But cf. Union Paving Co. ex rel. United States Cas. Co. v. Thomas, 103 F. Supp. 408, 410 (E.D. Pa. 1951) (dictum), aff'd per curiam, 195 F.2d 184 (3d Cir. 1952).

22 E.g., Stoneboro \& Chautauqua Lake Ice Co. v. Lake Shore \& M. So. Ry., 238 Pa. 289, 86 Atl. 87 (1913); Rundell \& Co. v. Lehigh Valley R.R., 254 Pa. 529, 532-33, 98 Atl. 1054, 1056 (1916) (dictum). Cf. Thomas v. First Nat'l Bank, $376 \mathrm{~Pa}$. 181, 101 A.2d 910 (1954) (banks) ; Bailey \& Co. v. Western Union Tel. Co., $227 \mathrm{~Pa} .522$, 76 Atl. 736 (1910) (public utilities) ; Downs v. Sley System Garages, $129 \mathrm{~Pa}$. Super. 68, 194 Atl. 772 (1937) (bailee for hire) ; Hoyt v. Clinton Hotel Co., $35 \mathrm{~Pa}$. Super. 297 (1908) (same). The invalidity of many exculpatory clauses may stem from unequal bargaining power, a factor that courts have failed to recognize in the modern leasing transaction. Annot., 175 A.L.R. 8, 17 (1948).

23 Annot., 175 A.L.R. 8, 21 (1948).

24 See Bryans v. Gallagher, $407 \mathrm{~Pa} .142,145,146,178$ A.2d 766, 767, 768 (1962) (dictum). 
a policy preventing the complete isolation of contracting parties from judicial processes, the courts have largely emasculated tenants' waiver of the right to open or strike confessed judgments or to seek appellate review. ${ }^{25}$ Although clauses waiving judicial review often are enforceable, ${ }^{26}$ the court can always disregard lease language to review fundamental challenges to the clause-for example, tenant's claim that he never executed the lease ${ }^{27}$ or that the lease had terminated before confession of judgment. ${ }^{28}$ To further prevent landlord's domination of tenant, however, landlord's warrant to confess judgment without judicial review is additionally restricted. Thus the clause is ineffective whenever tenant questions landlord's authority to confess judgment, ${ }^{29}$ although tenant may be precluded from attacking minor procedural irregularities. ${ }^{30}$ The settled treatment of the largely unenforceable waiver might justify its retention in the form 50 lease to secure predictable legal consequences. Nevertheless, narrowing the clause to its actual legal import would prevent landlords' use of formidable, but impotent, language to intimidate tenants. ${ }^{31}$

\section{B. Common-Law Doctrines}

\section{The Effect of Exculpatory Clauses on Non-Signers}

Under the prevailing view an exculpatory clause does not release landlord's liability to non-signers of the lease. ${ }^{32}$ Despite the fundamental fairness of this rule, the Pennsylvania Supreme Court has avoided the question

25 Form 50 lease, II 19. Compare Kros v. Bacall Textile Corp., $386 \mathrm{~Pa} .360$, 126 A.2d 421 (1956), and Grady v. Schiffer, 384 Pa. 302, 121 A.2d 71 (1956), with Casnoff v. Geddes, $160 \mathrm{~Pa}$. Super. 456, 51 A.2d 526 (1947). See also Boggs v. Levin, 297 Pa. 131, 146 Atl. 533 (1929) ; Curry v. Bacharach Quality Shops, Inc., 271 Pa. 364, 117 Atl. 435 (1921); Philadelphia v. Johnson, 23 Pa. Super. 591 (1903), aff'd, 208 Pa. 645, 57 Atl. 363 (1904).

26 E.g., Hindman v. Doughty, 172 Pa. 573, 33 Atl. 563 (1896) ; Cawley v. Bohan, $120 \mathrm{~Pa}$. 295, 14 Atl. 59 (1888); Consumers Mining Co. v. Chatak, $92 \mathrm{~Pa}$. Super. 17 (1927).

27 Mandel v. Freeland, $95 \mathrm{~Pa}$. Super. 228 (1928).

28 Willis-Winchester Co. v. Clay, $293 \mathrm{~Pa}$. 513, 143 Atl. 227 (1928).

29 E.g., Grady v. Schiffer, 384 Pa. 302, 121 A.2d 71 (1956) (form 50) ; Boggs v. Levin, $297 \mathrm{~Pa} .131,146$ Atl. 533 (1924); Polis v. Russell, $161 \mathrm{~Pa}$. Super. 456, 55 A.2d 558 (1947); Markheim-Chalmers-Ludington, Inc. v. Mead, $140 \mathrm{~Pa}$. Super. 490, 14 A.2d 152 (1940); cf. Kros v. Bacall Textile Corp., 386 Pa. 360, 126 A.2d 421 (1956) (form 50).

30 E.g., West Penn Sand \& Gravel Co. v. Shippingport Sand Co., 367 Pa. 218, 80 A.2d 84 (1951); Casnoff v. Geddes, 160 Pa. Super. 456, 51 A.2d 526 (1947) (form 50); Schwartz v. Goldin, $160 \mathrm{~Pa}$. Super. 625, 52 A.2d 737 (1947) (per curiam). $31 \mathrm{~A}$ landlord . . . may never resort to his ironclad document save when for extraneous reasons the other party proves unworkable. . . The problem is therefore seldom one of a practice of tyranny .... It is rather a problem of legal power which makes tyranny possible at arbitrary will ....

Llewellyn, What Price Contract?-An Essay in Perspective, 40 Yale L.J. 705, 736 (1931).

32 E.g., B. Shoninger Co. v. Mann, 219 IIl. 242, 76 N.E. 354 (1905) ; Valentin v. D. G. Swanson \& Co., 25 Ill. App. 2d 285, 167 N.E.2d 14 (1960) ; Goldberg v. Wunderlich, $248 \mathrm{Ky} .798,801,59$ S.W.2d 1018, 1020 (1933); Bryant v. Auchmuty, 129 N.Y. Supp. 471 (Sup. Ct. 1911). Contra, Telless v. Gardiner, 266 Mass. 90, 164 N.E. 914 (1929). 
in the leasing context, ${ }^{33}$ basing its decisions on other grounds, and the common pleas courts are in conflict. ${ }^{34}$ In Schetter $v$. United States, ${ }^{35}$ however, a federal district court held that under Pennsylvania law a tenant's release does not release claims of tenant's minor children, who were not parties to the lease. Instead of disposing of the landlord's defense merely on the basis that the children, as non-signers, could not be bound, the court also stressed that minors are protected by a legal incapacity to release their rights against tort-feasors. ${ }^{36}$ An implication of the decision is that the tenant's release, though ineffective against minors, may bind non-signers of legal capacity who voluntarily enter the premises. An alternative reading of Schetter, which reconciles it with the weight of authority, would simply rest the decision on the fact that the children were not privy to the contract. The court might have introduced the policy of protecting minors only to refute landlord's contention that parents' signatures should at least bind children, who may not otherwise be bound without cumbersome court proceedings. ${ }^{37}$ Any restrictions upon the effectiveness of an exculpatory clause against non-signers pertains to the form 50 lease only to the extent that landlord cannot recover under the lease's indemnity clause-for example, because of tenant's lack of sufficient assets or his unavailability for service of process.

\section{Construction of Contract Language}

Generally applicable principles of contract interpretation may vary the literal meaning of several form 50 provisions, particularly those of broad and ambiguous scope. If landlord is unable to give tenant possession on the first day of the term, "all rights and remedies of both parties hereunder

33 Baldwin v. McEldowney, 324 Pa. 399, 188 Atl. 154 (1936). Compare McIntyre v. Port View Dwellings, Inc, 109 Pittsb. Leg. J. 22, 30 (C.P. Allegheny County, Pa., 1960), with Strothman v. Houggy, 186 Pa. Super. 638, 142 A.2d 769 (1958) (both interpreting Baldwin). See also Burns v. N. \& L. Realty Corp., 174 F. Supp. 767 (W.D. Pa. 1959) (issue not raised).

34 Compare McIntyre v. Port View Dwellings, Inc., supra note 33, with McDonough v. Plantholt, 76 Pa. D. \& C. 119, 123 (C.P. Phila. County 1951) (form 50). See also Darrow v. Keystone 5, 10, 25, \$1.00 Stores, Inc., 60 Dauph. Co. Rep. 317 (C.P. Dauphin County, Pa.), rev'd on other gronnds, $365 \mathrm{~Pa} .123,74$ A.2d 176 (1950), which held that since an exculpatory clause bars tenant, it also bars those on the property in tenant's right, including his family. In support the court cited cases describing landlord's common-law duty to any person on the demised premises. This question differs from whether landlord can contractually avoid liability to nonsigners.

35136 F. Supp. 931, 935 (W.D. Pa. 1956).

36 Id. at 935-36; cf. PA. R. CIv. P. 2064 (court approval required to settle suits to which an incompetent is a party); Brill v. Brill, 282 Pa. 276, 127 Atl. 840 (1925); Hollinger v. York Ry., 225 Pa. 419, 74 Atl. 344 (1909) ; Campbell v. Sears, Roebuck \& Co., 307 Pa. 365, 369-70, 161 At1. 310, 312 (1932) (dictum). See also Fedor v. Mauwehu Council, Boy Scouts of America, Inc., 21 Conn. Supp. 38, 143 A.2d 466 (Super. Ct. 1958).

37 See, e.g., Spivak v. Bronstein, $367 \mathrm{~Pa} .70,75,79$ A.2d 205, 207 (1951); Fassitt v. Seip, $249 \mathrm{~Pa}$ 576, 594, 95 Atl. 273, 278 (1915) ; Kelly v. Ochiltree Elec. Co., 140 Pa. Super. 265, 273, 14 A.2d 351, 355 (1940); cf. PA. Stat. AnN. tit. 20, $\S 320.1044(1950)$. 
. . . [are] suspended" until he can. ${ }^{38}$ Nowhere does the lease provide for premature termination by the tenant, unless the premises are totally destroyed. ${ }^{39}$ If for some reason other than total destruction landlord were unable to give possession for an unreasonable period, tenant seemingly could be obligated for a term so short that the lease would have no value to him. A court apprised of these economic realities should hold that the parties must have intended the lease to terminate in these circumstances. ${ }^{40}$

Another clatuse forbids the use of machinery which "in Lessor's opinion" harms the building or disturbs other tenants. ${ }^{41} \mathrm{~A}$ reasonable interpretation might interpose a "good faith" qualification based on the testimony of building experts and other tenants. However, the vague clause prohibiting tenant from conducting himself in a manner which the landlord "in its sole opinion may deem improper or objectionable" 42 apparently gives landlord unfettered discretion to terminate the leasehold by calling any of tenant's conduct "objectionable." 43 If this extreme result were intended, the drafters could have expressly made the lease terminable at landlord's option. Thus the clause seems to contemplate some restriction on landlord's power. The absence of limiting standards, however, renders the clause so indefinite that a court, unable to give it any meaning, should hold it unenforceable. ${ }^{44}$

In some instances internal inconsistencies render otherwise valid provisions ineffective. Paragraph 2, which describes the parties' proposed use of the demised premises, is potentially inconsistent with other clauses in the lease. Since this expression of intent is added to the form by the parties, it takes precedence over the printed portion of the lease. ${ }^{45}$ For example, if the premises were intended as a retail store, a court would understandably hesitate to enforce paragraph $9(\mathrm{c})$, which prohibits tenant from placing a sign on the demised premises.

In Dilks v. Flohr Chevrolet, Inc. ${ }^{46}$ inconsistent implications in the form 50 lease were resolved by a common pleas court, holding that tenant

38 Form 50 lease, to 5 . (Emphasis added.)

39 Id. $\int 12(\mathrm{a})$.

40 Cf. Soco v. Roxas, 26 Philippine Rep. 609, 614 (1914).

41 Form 50 lease, $\llbracket 9(e)$.

42 Id. $\pi 13$ (d).

43 This unlimited power to terminate would not invalidate the lease for lack of consideration since the parties express their intent to be bound. UNIFORMA WRITTEN Obligations Act $\$ 1$; PA. Stat. ANn. tit. 33, \&6 (1949). Since a definite term is stipulated, the tenancy is not reduced to a tenancy at will. Compare Goodman v. R-W Realty Co., 115 Pa. Super. 237, 175 Atl. 302 (1934), with Lyons v. Philadelphia and R. Ry., 209 Pa. 550, 58 Atl. 924 (1904) (per curiam). See generally Annot., 137 A.L.R. 362, 366-69 (1942).

44 See, e.g., Beachler v. Mellon-Stuart Co., 354 Pa. 341, 47 A.2d 147 (1946); Brehm v. Brehm, 347 Pa. 271, 32 A.2d 216 (1943).

45 Onofrey v. Wolliver, 351 Pa. 18, 40 A.2d 35 (1945); Commonwealth v. Friedman, $121 \mathrm{~Pa}$. Super. 591, 184 Atl. 672 (1936); Mailey v. Rubin, $388 \mathrm{~Pa}$. 75, 130 A.2d 182 (1957) (dictum).

4681 Montg. Co. L. Rptr. 51 (C.P. Montgomery County, Pa., 1962). 
was not liable for fires caused by his negligence. In paragraph 8 (b) tenant agrees to keep the premises in good order except for "damage by accidental fire or other casualty not occurring through negligence of Lessee." The Dilks court construed "not occurring through negligence of Lessee" to modify only the words "other casualty," the word "or" effectively isolating "accidental fire." The court held that because a fire caused by tenant's negligence is an "accidental fire," paragraph 8 (b) effectively exculpated tenant from liability for damage from fires caused by his negligence. The court supported this strained result with paragraph $9(\mathrm{~g})$, which forbids tenant to cause fire insurance to be suspended or the premiums to be increased by doing any act objectionable to the fire insurance company. Breach of this covenant expressly obligates tenant only for the increase in lessor's fire insurance premiums. Relying on this paragraph to demonstrate that landlord intended to obtain fire insurance, ${ }^{47}$ the court found that the parties contemplated that landlord would bear all risk of fire. The intent gleaned from paragraphs $8(\mathrm{~b})$ and $9(\mathrm{~g})$ was deemed sufficiently clear to overcome potential contradiction by more general covenants that tenant "use every reasonable precaution against fire" 48 and that "Lessee agrees to pay . . . any and all damages to the demised premises caused by any act or neglect of the Lessee." 40

The Dilks interpretation of the form 50 lease best accommodates the parties' economic interests in light of their surrounding circumstances. The party ultimately responsible for fire loss due to tenant's negligence probably will insure against this potentially substantial risk. Yet the cost of insuring will normally be borne by the tenant, either indirectly by its inclusion in the amount of rent ${ }^{50}$ or by tenant's direct payment of premiums. In a multi-tenant building each tenant's insurance against the potential loss of the entire building would probably subject him to greater individual expense than his proportionate share of a single policy insuring the landlord. ${ }^{51}$ Moreover, tenant would have greater difficulty than landlord in procuring fire insurance since the standard policy covers only property owned by the insured, and therefore little risk experience is available for tenants' insurance. ${ }^{52}$

47 See General Mills v. Goldman, 184 F.2d 359 (8th Cir. 1950) ; Cerny-Pickas \& Co. v. C. R. Jahn Co., 7 Ill. 2d 393, 131 N.E.2d 100 (1956). See generally Brewer, An Inductive Approach to the Liability of the Tenant for Negligence, 31 B.U.L. REv. 47 (1951). But see Winkler v. Appalachian Amusement Co., 238 N.C. 589, 79 S.E.2d 185 (1953).

48 Form 50 lease, $\llbracket 8(d)$.

49 Id. I 6(a). This clause probably was not raised by the plaintiff.

50 See Form 50 lease, $\pi$ (I) $6(\mathrm{c})$ and $9(\mathrm{~g})$. Landlord's release of tenant from liability for negligent fires might violate landlord's insurance contract causing it to lapse. See Friedman, Landlords, Tenants and Fires-Insurer's Right of Subrogation, 43 CoRN. L.Q. 225 (1957). The landlord could avoid this difficulty by obtaining the company's consent to the lease. Id. at 232.

51 See Friedman, supra note 50, at 227 n.9, 227-29.

52 See Matan, Liability for Loss by Fire Among Insurer, Tenant and Landlord, 25 INs. Counsel J. 335, 341 (1958). 


\section{Inapplicability of Form 50 Language to Individual Situations}

The usual contract form-such as an insurance policy ${ }^{53}$ or a form sales contract ${ }^{54}$-is designed to promote both clerical convenience and uniform legal relations of the drafter in numerous relatively homogeneous transactions. The form lease, however, is intended to embody the agreements of parties other than the drafter in many varied leasing situations. Therefore, many of the clauses necessarily have no application to a given tenancy.

Inapplicable provisions frequently are nullified due to their inconsistency with the proposed use of the demised premises as written into the lease..$^{55}$ A court need not always require a patent inconsistency, however, before construing a seemingly unreasonable lease provision against the literal meaning of the language. Although paragraph 9 (e) ${ }^{56}$ of the form 50 lease suggests that the lease may be used for multi-tenant buildings, many other clauses seem so unreasonable in a multi-tenant context that a court would not literally enforce them. Thus paragraph $8(h)$ requires tenant to maintain the pavement and to be responsible for accidents occurring due to its defective condition. Rather than impose these duties on a fourth-floor tenant, a court might disregard the clause unless there were pavement adjoining the demised premises. Similarly, despite the clear language of paragraph $6(\mathrm{~b})$-requiring tenant to pay all taxes assessed "upon the demised premises and/or the building of which the demised premises is a part"-a court would probably strain to avoid obligating a tenant of a multi-tenant building to pay the entire tax assessed against the whole building.

A common pleas court faced a similar problem of limiting inapplicable language in Williams v. Wolf. ${ }^{57}$ Plaintiff, injured by a defective floorboard in landlord's portion of a ground floor store in which landlord and tenant operated separate businesses, sought to satisfy his judgment ${ }^{58}$ against landlord by garnishing tenant's alleged indemnity obligation under paragraph 12 of the form 50 lease: "Lessee also agrees . . . to relieve . . . Lessor from all liability . . . from any kind of injury which may arise from any other cause whatsoever [in] . . . the building of which the demised premises is a part . . . " (Emphasis added.) The court denied indemnification finding that the dominant intent of the quoted clause and the immediately preceding indemnity provisions was to limit indemnity to accidents in which either the injury or its cause occurred on the demised premises. But reliance upon specific language of prior clauses to limit injuries or causes to those on the demised premises seems misplaced, since the repeated use of such limiting language followed by its omission could

53 See Kessler, Contracts of Adhesion-Some Thoughts About Freedom of Contract, 43 Colum. L. REv. 629, 630-31 (1943).

54 See Shuchman, Consumer Credit by Adhesion Contracts, 35 Temp. L.Q. 125, 127-28 (1962).

55 See p. 1202 supra.

56 Tenant may not use machinery disturbing to other tenants in the building.

5783 Pa. D. \& C. 399 (C.P. Phila. County 1952) (form 50 lease).

58 See Williams v. Wolf, 169 Pa. Super. 628, 84 A.2d 215 (1951). 
imply that the omission was intentional. The construction of the indemnity clause was actually prompted less by its ambiguity than by its unreasonable breadth. Identifying the lease as a standard form, the court relied on the harsh consequences that might ensue were the clause literally applied to a hypothetical apartment or office building.

The merit of the Williams decision is that it implicitly recognizes the source of the difficulty-the use of a standard form in diverse leasing transactions. Construing the language in light of hypothetical cases, however, obscures this problem by neglecting the objective intent of the parties actually before the court. To the extent that judicial definition of this standard clause achieves an independent precedent value, the danger increases that it will be automatically applied without examination of the circumstances surrounding the particular transaction. Although standardized provisions promote predictability of legal consequences, ${ }^{59}$ the form lease is not private legislation to be uniformly applied as interpreted by the courts. Each use of the form is a discrete contract, whose meaning should derive from the words viewed in light of the circumstances unique to the parties. ${ }^{60}$ Among the surrounding circumstances relevant to the interpretation of the contract language is the parties' use of a standard form designed to accommodate varying situations. Since a form contract is construed most strictly against the party for whom it was drafted, ${ }^{61}$ a court could justifiably assume that non-specific language in a widely used form was not meant to produce harsh results ${ }^{62}$ - provided the reasonable application of the language in a different lease situation explains its insertion in the form. ${ }^{63}$ But precise language, or broad language that cannot reasonably apply to another likely situation, negates the possibility that the harshness derives from applying the clause in a setting not envisioned by the draftsmen. Thus increasingly exact phrasing of the lease would require other judicial approaches to mitigate its severity.

\section{Judicial Responses to AdHesion Elements in Form Leases}

\section{A. The Possibility of Judicial Invalidation of Form Lease Provisions}

The distinguishing feature of adhesion contracts is lack of negotiationthe imposition of terms by the drafting party upon the adhering party. ${ }^{64}$

59 See Kessler, supra note 53, at 632 .

60 Cf., e.g., Satterwhite v. National Powder Co., 362 Pa. 133, 66 A.2d 278 (1949); Portage Mercantile Co. v. Johnstown Coal \& Coke Co., 356 Pa. 557, 52 A.2d 452 (1947).

61 Brookbank v. Benedum Trees Oil Co., $389 \mathrm{~Pa} .151,158,131$ A.2d 103, 108 (1957); Sanctis Constr., Inc., Arbitration Case, 158 Pa. Super. 71, 43 A.2d 581 (1945).

62 Cf. Hindman v. Farren, 353 Pa. 33, 44 A.2d 241 (1945); Garvin \& Co. v. Lancaster County, $290 \mathrm{~Pa} .448,139$ Atl. 154 (1927); Ellis v. Lane, $85 \mathrm{~Pa} .265$ (1877).

${ }^{63}$ The broad language of paragraph 12 could reasonably be restricted to indemnification for injuries occurring on tenant's premises or those suffered by tenant's invitee.

64 See Ehrenzweig, Adhesion Contracts in the Conflict of Laws, 53 Couum. L. REV. 1072, 1075 (1953). 
Its cause is frequently disparity in economic power between the parties, ${ }^{65}$ but even more significant in the leasing context is the general disinclination of small tenants to seek legal advice. Analysis of the form lease in terms of traditional contract principles devised for negotiated transactions erroneously assumes that its intricate clauses, drafted solely for landlord's benefit, also embody tenant's intent. ${ }^{6 B}$ Although courts working from this premise can often avoid unconscionable results by construction, ${ }^{67}$ inequity may result when harsh clauses are unambiguous. ${ }^{68}$ Furthermore, strained constructions of common phrases may be uncritically extended to negotiated contracts to contradict the actual intent of parties who have relied on the natural meaning of contract language. To protect their interests landlords may try to negate unfavorable judicial interpretation of form lease provisions by rephrasing them more precisely. ${ }^{60}$ Ultimately the court must either uphold unambiguous clauses despite their harshness or hold them unenforceable solely because of the adhesion elements of the contract.

In the landmark case of Henningsen $v$. Bloomfield Motors, Inc., ${ }^{70}$ the Supreme Court of New Jersey, recognizing factors unique to adhesion contracts, held unenforceable a disclaimer of the implied warranty of merchantability in a standard automobile purchase contract. Construing the Uniform Sales Act to authorize disclaimers of warranty only in a framework of free negotiation, ${ }^{71}$ the court rested on the unavoidability of purchaser's accepting a burdensome clause standardized throughout the industry. ${ }^{72}$ Other adhesion elements bolstering the court's opinion were the possibility that technical language would mislead laymen ${ }^{73}$ and the deemphasis of the harsh clause in the physical format of the contract. ${ }^{74}$ This stress on the peculiarities of adhesion contracts rarely appears in Pennsylvania opinions, ${ }^{75}$ but the impact of harshness and absence of negotiation readily harmonizes otherwise inconsistent decisions.

65 Kessler, Contracts of Adhesion-Some Thoughts About Freedom of Contract, 43 CoLUM. L. REv. 629 (1943); Shuchman, sipra note 54, at 129.

68 See generally Kessier, supra note 65 , at $640-41$.

${ }^{67}$ E.g., American Bowling Club v. Kanefsky, $370 \mathrm{~Pa}$ 136, 87 A.2d 646 (1952) (form 50 lease); Matovich v. Gradich, $123 \mathrm{~Pa}$. Super. 355 (1935).

68 Sanford-Day Iron Works v. Fancy Hill Coal Co., $321 \mathrm{~Pa} .204,206,183$ At1. $770,771-72$ (1936). Compare Shafer v. Reo Motors, Inc., 205 F.2d 685 (3d Cir. 1953), with Henningsen v. Bloomfield Motors, Inc., 32 N.J. 358, 161 A.2d 69 (1960).

${ }^{69}$ In Grady v. Schiffer, 384 Pa. 302, 121 A.2d 71 (1956) (form 50), the landlord was unable to confess judgment for loss of property allegedly removed by tenant since the warrant of attorney only authorized confessed judgments "for rent or charges reserved as rent." Subsequent revisions of clause 6(a) specified that such costs were recoverable "as rent."

7032 N.J. 358, 161 A.2d 69 (1960).

71 Id. at 404,161 A.2d at 95.

72 Ibid.

73 Id. at $399-400,161$ A.2d at $92-93$.

74 Id. at 399,161 A.2d at 92 .

${ }^{75}$ Cf. Campbell Soup Co. v. Wentz, 172 F.2d 80 (3d Cir. 1948). Courts applying section 2-302 of the Uniform Commercial Code, PA. STAT. ANN. tit. 12A, \$2-302 (Supp. 1962), providing for the unenforceability of unconscionable sales contract provisions may develop standards of unconscionability useful in dealing with form leases. 


\section{B. The Effect of Adhesion Elements on Judicial Construction of Indemnity Clauses}

\section{Harshness}

In Perry v. Payne, ${ }^{76}$ a leading Pennsylvania case construing indemnity clauses, a subcontractor's employee had been killed on landowner's property by the negligent operation of an elevator by landowner's employee. Despite the prime contractor's agreement to indemnify landowner for "all loss, cost or expense ... arising from accidents to . . . laborers employed in the construction," the court refused indemnity absent specific provision in the indemnity clause for landowner's negligence. The circumstance that the contractor was to occupy the property during construction indicated that the parties had contemplated indemnification for accidents caused by the contractor, ${ }^{77}$ and not those caused by the landowner's active negligence.

This characterization of the parties' presumed intent does not comport with the construction of parallel language in lease exculpatory clauses. In Cannon v. Bresch ${ }^{78}$ tenant sought recovery for property damage caused by landlord's negligence in permitting water to leak from rooms occupied by landlord above the demised premises. Under the exculpatory clause the tenant released landlord "from any and all liability for damage" from specified sources. Rejecting tenant's claim that the clause did not release landlord's liability for his own negligence, the court reasoned that unless landlord were exculpated from his own negligence, the clause would never have application. ${ }^{79}$ Had the Perry approach been employed, ${ }^{80}$ however, the absence of a specific reference to landlord's negligence in the exculpatory clause would have required the court to determine the clause's anticipated scope from the surrounding circumstances. Although the parties to a lease may foresee accidents caused by defective conditions on the demised premises or negligent performance of landlord's duties under the lease, they are not likely to contemplate landlord's negligence in a capacity independent of their contractual relationship. ${ }^{81}$ The acts of negligence in Cannon and Perry thus seem equally remote from the parties' natural expectations. The disparate constructions of comparably broad clauses might be due to the substantive difference between exculpatory and indemnity clauses. Whereas a lease exculpatory clause shifts to tenant only his own loss from landlord's

76217 Pa. 252, 66 Atl. 553 (1907).

77 Id. at $257-59,66$ Atl. at 555 . (1926).

$78307 \mathrm{~Pa}$. 31, 160 Atl. 595 (1932) ; accord, Lerner v. Heicklin, 89 Pa. Super. 234

79 Cannon v. Bresch, 307 Pa. 31, 36, 160 Atl. 595, 597 (1932).

80 Although Perry has been treated as a per se rule requiring unequivocal language for an indemnity obligation to include liability arising from indemnitee's negligence, e.g., Burns v. N \& I Realty Corp., 160 F. Supp. 203 (W.D. Pa. 1958), many cases cite it for the rule that agreements must be construed in light of surrounding circumstances, e.g., Schroeder v. Gulf Ref. Co., 300 Pa. 405, 411, 150 Atl. 665, 667 (1930); Van Horn v. Kemena, $281 \mathrm{~Pa} .579,581,127$ Atl. 233 (1924).

81 See, e.g., Cairnes v. Hillman Drug Co., 214 Ala. 545, 108 So. 362 (1926); Simmons v. Pagones, 66 S.D. 296, 282 N.W. 257 (1938); Annot., 175 A.L.R. 8, 89-92 (1948). 
negligence, an indemnity clause places upon the indemnitor responsibility for injury to an unascertained number of people whose carefulness he cannot readily police. Consequently Cannon and Perry illustrate that the court's construction of parallel vague language tends to vary with the inherent harshness of the clause.

\section{Lack of Negotiation}

Seemingly harsh language negotiated by the parties deserves literal construction since it presumptively expresses their precise intent. Similarly worded clauses in form adhesion contracts, however, by subsuming uncontemplated contingencies, often impose hardships on the adhering party. Implicitly weighing the likelihood of non-negotiation as a surrounding circumstance bearing on the parties' objective intent, Pennsylvania courts have variously construed apparently equivalent lease indemnity clauses to avoid unreasonable results.

In Tidewater Field Warehouses, Inc. v. Fred Whitaker Co., ${ }^{82}$ contrary to the customary lease arrangement, landlord had agreed to indemnify tenant for "all damages to property or persons upon the demised premises." The lease, which had been transacted solely to avoid immediate payment of an import duty on landlord's wool by complying with the government requirement of storage in a bonded warehouse, empowered landlord to select warehouse employees, who would be subject to tenant's technical control.83 Tenant sought indemnity after being adjudged vicariously liable for the negligence of a warehouse workman. ${ }^{84}$ Although the broad indemnity clause did not specifically require payment for the negligence of tenant-indemnitee, the court's inquiry into the circumstances surrounding this unusual transaction convinced it that indemnification of the tenant for all liability was probably a focal point of the negotiations, since the landlord alone was effectively to control the warehousing operation. Since the parties bargained for the clause, the court properly enforced the broad language literally.

Broad indemnity clauses in construction contracts are vital to the landowner because the inherently hazardous work, frequently beyond his close control, threatens injury to the many people who may enter the property. The surrounding circumstances, however, rarely compel the inference of actual negotiation to support the clause's literal application as clearly as in Tidewater. Consequently courts must scrutinize the background of the agreement to determine the objective intent embodied in broadly worded indemnity clauses. The parties' expectations normally embrace indemnification for negligent defects on the premises or acts of the building contractor. ${ }^{85}$

$82370 \mathrm{~Pa} .538,88$ A.2d 796 (1952).

83 See Pittsburgh Steel Co. v. Patterson-Emerson-Comstock, Inc., 404 Pa. 53, 60, 171 A.2d 185, 189 (1961).

84 Donnelly v. Fred Whittaker Co., $364 \mathrm{~Pa}$.387, 72 A.2d 61 (1950).

85 Cf. First Presbyterian Congregation v. Smith, 163 Pa. 501, 30 Atl. 279 (1894); Baier v. Glen Alden Coal Co., 131 Pa. Super. 309, 200 Atl. 190 (1938), aff'd, 332 Pa. 561, 3 A.2d 349 (1939). 
Indemnification for landowner's active negligence, however, is rarely contemplated unless landowner is to be a coparticipant in the activity performed by the contractor under the construction contract. Accordingly, indemnification has been denied where landowner was expected to vacate the premises during construction, ${ }^{86}$ and where the negligent employees were under his exclusive control. ${ }^{87}$ Nevertheless, if the landowner's employees were to work under the direction of the contractor, a court could justifiably assume that the parties contemplated coverage of the employees' negligence by a broad indemnity clause.

The indemnity clause of the form lease would seldom interest a prospective tenant not conversant with the form's technicalities. Since a leasing transaction does not inevitably increase the possibility of third party injury-as does a construction contract-, a tenant is not apt to anticipate accidents to third parties, much less negotiate the incidence of potential tort liability. Hence, a broad indemnity clause need not obligate tenant should landlord injure a third party by negligently performing his janitorial duties described in the lease. ${ }^{88}$ Absent negotiation, it would be harsh to hold tenant accountable for the negligence of workmen under landlord's control. A court could reasonably maintain that tenant expected to indemnify only for damage caused by that negligence of the landlord which tenant, due to his occupancy of the premises, had an equal or superior opportunity to prevent-such as landlord's passive negligence in permitting defective conditions to arise on the property-rather than the active negligence of landlord or agents within his control. ${ }^{89}$

The courts habitually rely on the forseeability of indemnitee's negligent act to mitigate harsh results when the indemnity clause is broadly worded. But the form 50 indemnity clause describes in detail tenant's obligation to indemnify for landlord's negligence. Nevertheless, specificity of language alters neither the potential harshness of the clause nor the likelihood that it was negotiated. Consistency thus demands that tenant's obligation to indemnify not be expanded by his unwitting acceptance of unusually precise form language.

\section{Confessions of Judgment}

Pennsylvania courts have also scrutinized form 50 warrants of attorney to confess judgment in an attempt to restrict their inherent harshness. Thus in American Bowling Club v. Kanefsky ${ }^{90}$ the supreme court held

80 Perry v. Payne, 217 Pa. 252, 66 Atl. 553 (1907).

87 Pittsburgh Steel Co. v. Patterson-Emerson-Comstock, Inc., 404 Pa. 53, 171 A.2d 185 (1961).

88 See Burns v. N \& L Realty Corp., 160 F. Supp. 203 (W.D. Pa. 1958).

80 Cf. Rolfe v. Tufts, 216 Mass. 563, 104 N.E. 341 (1914); Drescher Rothberg Co. v. Landeker, 140 N.Y. Supp. 1025 (Sup. Ct. 1913) ; Railton v. Taylor, 20 R.I. 279, 38 Atl. 980 (1897); Annot., 175 A.L.R. 8, $89-92$ (1948).

90370 Pa. 136, 87 A.2d 646 (1952) (form 50 lease); accord, Weinroth v. Loev, $77 \mathrm{~Pa}$. D. \& C. 385 (C.P. Phila. County 1951) (form 50 lease). 
that landlord had no authority to enter successive confessions of judgment for the same rent even though the first entry of judgment was abortive. The court apparently ignored the lease's clear language-different from that in all prior cases" ${ }^{91}$ - that authority to confess judgment "shall not be exhausted by one exercise thereof, but judgment may be confessed . . . from time to time as often as any of said rent . . . shall fall due or be in arrears." 92 The court conceded that the clause would validly authorize successive judgments for different defaults. ${ }^{93}$ Confessing judgment a second time upon the same valid claim, following an initial void exercise of the power, seems only imperceptibly more burdensome on tenant. ${ }^{94}$ Moreover, if the defect in the first judgment was simply a procedural technicality, denial of landlord's cause of action seems unwarranted.

American Bowling's arbitrary distinction between multiple confessed judgments for the same and for different claims suggests that since all confessions of judgment are harsh, the court will restrict them whenever possible. ${ }^{95}$ The technique of construing the language, however, compelled the court to acknowledge that specific provision for successive judgments for the same rent would have validated the second confession. To require the landlord to cast the warrant of attorney in a particular verbal formula does not strike at the evil-the ubiquity of warrants of attorney in adhesion contracts and the attendant unwitting acceptance of the clause by the tenant. By articulating the relation between lack of negotiation and harsh lease clauses, the courts could mitigate oppressive results without awkward constructions.

Although the form 50 confession of judgment clause has often been construed strictly to favor tenant without express attention to the adhesion elements of the contract, ${ }^{96}$ the Pennsylvania courts have decided confession of judgment cases in other contexts upon adhesion principles. In Cutler Corp. v. Latshawe ${ }^{97}$ the court invalidated a confession of judgment clause

$91370 \mathrm{~Pa} .136,140-41,87$ A.2d 646, 648 (1952) (dissenting opinion). See, e.g., Hogsett v. Lutrario, 140 Pa. Super. 419, 424, 13 A.2d 902,904 (1940) ; S. Jacobs \& Son v. Busedu, 95 Pa. Super. 132 (1928); Philadelphia v. Johnson, 23 Pa. Super. 591, aff'd, $208 \mathrm{~Pa}$ 645, 57 Atl. 1114 (1904), See generally Annot., 80 A.I.R.2d 1380 (1961).

92 Form 50 lease, $\mathbb{1}$ 16. (Emphasis added.)

93 American Bowling Club v. Kanefsky, 370 Pa. 136, 138, 87 A.2d 646, 647 (1952).

94 Most jurisdictions permit successive confessions of judgment for the same rent without express authorization, if the first judgment is void. E.g., Turner v. Alton Banking \& Trust Co., 181 F.2d 899 ( 8 th Cir.), cert. denied, 340 U.S. 833 (1950) ; Hoyt v. Morris, 216 Ill. App. 321 (1920) ; Huner v. Doolittle, 3 Greene 76 (Iowa 1851); see Annot., 80 A.L.R.2d 1380, 1382 (1961).

95 Cutler Corp. v. Latshaw, 374 Pa. 1, 4-5, 97 A.2d 234, 236 (1953) (dictum); see, e.g., Ahern v. Standard Realty Co., 267 Pa. 404, 405, 110 Atl. 141 (1920); Stewart v. Lawson, $181 \mathrm{~Pa}$ 549, 550, 37 Atl. 518, 519 (1897) ; cf. Solazo v. Boyle, $365 \mathrm{~Pa}$. 586, 76 A.2d 179 (1950).

${ }^{86}$ E.g., Grady v. Schiffer, 384 Pa. 302, 121 A.2d 71 (1956) ; American Bowling Club v. Kanefsky, $370 \mathrm{~Pa}$ 136, 87 A.2d 646 (1952); Gratz Bros. v. Margolis, 186 Pa. Super. 268, 142 A.2d 375 (1958).

$97374 \mathrm{~Pa} .1$, 97 A.2d 234 (1953) ; accord, Frantz Tractor Co. v. Wyoming Valley Nursery, 384 Pa. 213, 120 A.2d 303 (1956). 
in a standard form construction contract solely because defendant had unknowingly accepted the clause. The face of the contract incorporated by reference finely printed conditions on the reverse, including a warrant of attorney to confess judgment. A list of handwritten specifications extended onto separate sheets without making use of spaces provided on the back of the form near the warrant of attorney. The narrow holding of Cutler - that a confession of judgment clause physically outside the consciously accepted writing does not bind the defendant-is inapplicable to the form 50 lease, since a partial sentence continues onto the side containing the warrants of attorney, which are designated by a marginal paragraph heading. Although the parties do not sign on this side of the form, ${ }^{98}$ there are spaces for information about the rental agent and the notice needed to terminate the lease. Omission of this information would bolster an argument based on Cutler that the tenant, concerned only with the essential aspects of the lease, was insufficiently aware that the warrant was part of the form.

\section{Landlord's Cumulative Remedies}

Among landlord's remedies for tenant's breach of form 50 covenants are termination of the leasehold ${ }^{99}$ and acceleration of the rent. ${ }^{100}$ Purporting to make landlord's remedies cumulative, the lease provides that recovery of the premises does not deprive landlord of a remedy "for rent due at the time or which, under the terms hereof, would in the future become due as if there had been no determination." 101 Absent such a specific provision in the lease, landlord could not both eject tenant and recover accelerated rent for the unexpired term. ${ }^{102}$ Although this rule has been supported by the doctrinal difficulty of charging rent on a nonexistent lease, ${ }^{103}$ courts are undoubtedly influenced by the harshness of cumulative remedies. ${ }^{104}$ Thus, despite dicta that specific language can effect a cumulation of remedies, ${ }^{105}$ it is unlikely that a court would permit a form 50 landlord to eject tenant and also to exact the full term rental.

${ }^{98} \mathrm{Cf}$. Shell Constr. Co. v. Griffing, $22 \mathrm{~Pa}$. D. \& C.2d 43 (C. P. Montgomery County 1960$)$.

99 Form 50 lease, II 14(1).

100 Id. $\llbracket 14(2)$.

101 Id. $\llbracket 21$.

102 Matovich v. Gradich, 123 Pa. Super. 355, 187 Atl. 65 (1936); DeLong Hook \& Eye Co. v. Vogue Silk Hosiery Co., 108 Pa. Super. 369, 164 Atl. 848 (1933); Greco v. Woodlawn Furniture Co., 99 Pa. Super. 290 (1930); Grakelow v. Kidder, $95 \mathrm{~Pa}$. Super. 250 (1928).

103 Grakelow v. Kidder, supra note 102 , at 255 .

104 Greco v. Woodlawn Furniture Co., 99 Pa. Super. 290, 292 (1930) ; Grakelow v. Kidder, $95 \mathrm{~Pa}$. Super. 250, 256 (1928).

105 Purvis v. Dempsey, 238 Pa. 173, 85 Atl. 1091 (1913) (per curiam) ; MarkeimChalmers-Ludington, Inc. v. Mead, 140 Pa. Super. 490, 14 A.2d 152 (1940) ; Grakelow v. Kidder, $95 \mathrm{~Pa}$. Super. 250 (1928). But cf. Charlson's Furniture Co. v. Heigley, $161 \mathrm{~Pa}$. Super. 24, 53 A.2d 878 (1947) (bailment lease); Rome Sales \& Serv. Station v. Finch, $120 \mathrm{~Pa}$. Super. 402, 183 Atl. 54 (1936) (bailment lease) ; Lukac v. Morris, $108 \mathrm{~Pa}$. Super. 453, 164 Atl. 834 (1933) (bailment lease). 
Alternative approaches are available to prevent an oppressive cumulation. Although the form 50 language might be construed to avoid cumulation, ${ }^{106}$ a strained reading not only creates a misleading precedent but also suggests that the defect may be cured by redrafting the lease. Similarly, the property concept ending rental obligations at the termination of the leasehold ${ }^{107}$ may easily be evaded by providing that landlord's right to eject arises only after the rent has accelerated.

An appropriate solution might be to analogize to the contract rule against penalty clauses, which voids unreasonable contractual stipulations of the amount of damages recoverable in the event of future breach. ${ }^{108}$ The rationale extends to the cumulation of ejectment and accelerated rent. Although the precise amount of potential damage is unknown when the lease is executed, the provision for cumulation obviously penalizes the tenant since it may require him to forego use of property for which he has paid accelerated rental. Moreover, a burdensome cumulation clause seems contrary to the normal expectations of form lease tenants. Thus a court, recognizing the adhesion elements of the form lease, might adopt a penalty rationale to hold this clause unenforceable. ${ }^{109}$

\section{CoNCLusion}

Reference to accepted contract doctrines disposes of many form lease controversies. Nevertheless, the assumption that standardized clauses peripheral to the basic rental transaction do not embody the bargained intent of the parties often seems implicit in the judicial avoidance of harsh results by nonliteral construction of language. Designation of the absence of negotiation in adhesion contracts as a surrounding circumstance pertinent to the objective intent of the parties is crucial to a reasoned judicial approach to this unique branch of contract law. Yet, the danger remains that a tenant with the economic power and legal advice requisite to negotiation of a lease may still sign the unaltered form to avoid losing whatever protection the law accords the weaker party to an unnegotiated agreement. The courts seem unsuited to determine whether an individual's economic resources and knowledge of the law enable him to negotiate. Similarly,

106 "Rent due" in paragraph 21 might be interpreted to mean rent actually due and not accelerated rent "taken to be due" under paragraph 14(1). C f. Baldwin v. American Motor Sales Co., 309 Pa. 275, 279, 163 Atl. 507, 508-09 (1932). "Rent . . . which . . . would in the future become due" might apply only to net loss of rent caused by a subsequent less favorable lease. See paragraph 15(c) ; cf. Park-Main Co. v. Fayette Nat'1 Bank \& Trust Co., $397 \mathrm{~Pa}$. 75, 80, 152 A.2d 714, 716-17 (1959). Furthermore, the specific disjunctive authorizations of ejectment and accelerated rent in paragraphs $14(1)$ and 14(2) might not have been intended to be overridden by the general cumulation clause of paragraph 21 .

107 See Grakelow v. Kidder, 95 Pa. Super. 250 (1928).

108 E.g., Lackawanna Boiler \& Grate Co. v. Lee Coal Storage Co., 290 Pa. 561, 139 At1. 315 (1927); Philadelphia Dairy Prods. Co. v. Polin, 147 Pa. Super. 26, 23 A.2d 221 (1941).

${ }^{109}$ See Park-Main Co. v. Fayette Nat'l Bank \& Trust Co., 21 Fayette L.J. 160, 164-65 (C.P. Fayette County, Pa., 1958), aff'd on other grounds, 397 Pa. 75, 152 A.2d 714 (1959). 
courts cannot prevent the use of judicially unenforceable language to intimidate unknowledgeable tenants. ${ }^{110}$

The solution of these problems may require legislative regulation of the format and contents of form leases. ${ }^{111}$ Supported by criminal sanctions, regulation could effectively prescribe formal requirements in model provisions that could be modified only on an individual basis. In the absence of a writing, the model provisions, supplemented by the actual agreements upon term and rent, would control. Tenant's opportunity to negotiate provisions deviating from this norm would be secure.

Steven A. Arbittier

110 Llewellyn, What Price Contract?-An Essay in Perspective, 40 Yale L.J. 704, 736 (1931).

111 Cf. PA. Stat. Ann. tit. 69, §613D (Supp. 1962) (contents and size of print specified for motor vehicle installment sale contract); PA. STAT. ANN. tit. $40, \S 636$ (Supp. 1962) (contents and size of print of fire insurance policies). 